\title{
Bacterial adsorption effect of smectite for wound-healing application
}

\author{
Yu SASAKI and Osamu YAMAMOTO \\ Bio-engineering, Graduate School of Science and Engineering, Yamagata University, \\ 4-3-16 Jonan, Yonezawa, Yamagata 992-8510, Japan
}

\begin{abstract}
Smectite containing $\mathrm{Zn}^{2+}$ or $\mathrm{Mg}^{2+}$ ions was synthesized by a solution process. The $\mathrm{X}$-ray diffraction patterns of the synthesized smectite powder corresponded to those of previous studies. In bacterial adsorption tests, smectite containing $\mathrm{Zn}^{2+}$ or $\mathrm{Mg}^{2+}$ ions was found to exhibit bacterial adsorption properties which were greater for smectite containing $\mathrm{Zn}^{2+}$ ion than for smectite containing $\mathrm{Mg}^{2+}$ ion. By observation, using the fluorescent staining method, the bacteria adsorbed on the smectite powder were confirmed as live bacteria. These results suggested that the bacterial adsorption can reduce bacterial infection.

(C2017 The Ceramic Society of Japan. All rights reserved.
\end{abstract}

Key-words : Bacterial adsorption, Powder, Smectite

[Received April 18, 2017; Accepted June 14, 2017]

Clay minerals have the property of adsorbing microorganisms, organic matter and gas by protonation and deprotonation at the edge of the crystal structure. ${ }^{1-3)}$ Smectite is a clay mineral that is present in nature. In aqueous solutions, it has the properties of viscosity increase and cation exchange. ${ }^{4), 5)}$ These properties possessed by smectite are important to cosmetics and skin-care products, ${ }^{6)}$ and clay therapists have used the powder on the skin of ladies who pursue diverse beauty.

In our previous report, we clarified that smectite containing $\mathrm{Zn}^{2+}$ ion (hereafter, $\mathrm{Zn}$-smectite) and $\mathrm{Mg}^{2+}$ ion (hereafter, $\mathrm{Mg}-$ smectite) are effective for skin tissue regeneration by releasing $\mathrm{Zn}^{2+}, \mathrm{Mg}^{2+}$ and $\mathrm{Si}^{4+}$ ions. ${ }^{7), 8)}$ Bioactive ions such as $\mathrm{Zn}^{2+}$ and $\mathrm{Mg}^{2+}$ are related to enzyme activity in the wound-healing process. ${ }^{9)-11)}$ Also in order to achieve satisfactory tissue regeneration, it is necessary to prevent the formation of biofilm during the wound-healing process. Formation of biofilm causes severe tissue damage by the secretion of reactive oxygen and matrix metalloproteinase from inflammatory cells such as neutrophils and macrophages. ${ }^{12)}$ Additionally, systemic inflammatory response syndrome such as septicemia may also be caused by biofilm formation. It should be noted that there are no scientific literature reports to clarify the interaction between bacteria and synthesized smectite powder. Therefore, this study needed to clarify the bacteria-smectite powder interaction of synthesized smectite using the bacterial adsorption test and the fluorescent staining method. In this paper, the bacterial adsorption properties using $\mathrm{Zn}$ - and $\mathrm{Mg}$-smectite are reported.

$0.096 \mathrm{~g}$ of Zinc chloride $\left(\mathrm{ZnCl}_{2}\right.$; Nacalai tesque, inc, Kyoto, Japan) was dissolved in distilled water to make a total volume of $60 \mathrm{ml}$. $0.099 \mathrm{~g}$ of sodium silicate solution $\left(\mathrm{Na}_{2} \mathrm{O} \cdot 2 \mathrm{SiO}_{2} \cdot x \mathrm{H}_{2} \mathrm{O}\right.$; Nacalai tesque, inc, Kyoto, Japan) was dissolved in distilled water to make a total volume of $80 \mathrm{ml}$. The $\mathrm{ZnCl}_{2}$ aqueous solution was added to the $\mathrm{Na}_{2} \mathrm{SiO}_{3}$ solution with the $\left(\mathrm{ZnCl}_{2} / \mathrm{Na}_{2} \mathrm{O}\right.$. $2 \mathrm{SiO}_{2} \cdot x \mathrm{H}_{2} \mathrm{O}$ ) at a volume ratio of 0.75 . The solution was adjusted to $\mathrm{pH} 8$ by addition of $0.1 \mathrm{~mol} / 1 \mathrm{NaOH}$ solution. $\mathrm{Zn}$-smectite was then obtained by refluxing the prepared solution at $90^{\circ} \mathrm{C}$ for $12 \mathrm{~h}$.

$\dagger$ Corresponding author: O. Yamamoto; E-mail: yamamoto@yz. yamagata-u.ac.jp
Mg-smectite was synthesized as follows: In brief, $12.19 \mathrm{~g}$ of magnesium chloride hexahydrate $\left(\mathrm{MgCl}_{2} \cdot 6 \mathrm{H}_{2} \mathrm{O}\right.$; Nacalai tesque, inc, Kyoto, Japan) was dissolved into distilled water to make a total volume of $26.6 \mathrm{ml}$ (solution A). $12.27 \mathrm{~g}$ of sodium silicate solution was dissolved into distilled water to make a total volume of $40 \mathrm{ml}$ (solution B). Solution B was then added to $650 \mathrm{ml}$ of distilled water, stirred at room temperature for $1 \mathrm{~h}$ and the $\mathrm{pH}$ of the solution was adjusted at 10.50 by the addition of $11 \mathrm{~mol} / 1$ hydrochloric acid $(\mathrm{HCl})$. Solution $\mathrm{A}$ and $1 \mathrm{~mol} / 1 \mathrm{NaOH}$ were added to the $\mathrm{pH}$-adjusted solution and stirred at room temperature for $6 \mathrm{~h}$. The $\mathrm{pH}$ level was maintained at 10 . After the generation of precipitates in the solution, the solution was centrifuged at $2000 \mathrm{rpm}$ for $5 \mathrm{~min}$ and yielded a white gelatinous precipitation. The precipitates were washed by filtration and dried at $70^{\circ} \mathrm{C}$. After $3.3 \mathrm{~g}$ of the dried precipitates were dispersed in a $\mathrm{NaOH}$ solution, the dispersed solution was placed in a pressure vessel. $\mathrm{Mg}$-smectite was then synthesized by hydrothermal treatment at $220^{\circ} \mathrm{C}$ for $6 \mathrm{~h}$.

The crystal structures of the synthesized powders were characterized using a powder X-ray diffraction meter (XRD; UltimaIV, Rigaku, Tokyo, Japan) with $\mathrm{Cu} \mathrm{K} \alpha$ radiation $(40 \mathrm{kV}, 40 \mathrm{~mA})$. Figure 1 shows the X-ray diffraction patterns of the synthesized powder. These diffraction peaks did correspond to $\mathrm{Zn}-$ and $\mathrm{Mg}$ smectite as reported in previous research. ${ }^{13), 14)}$ The reason that

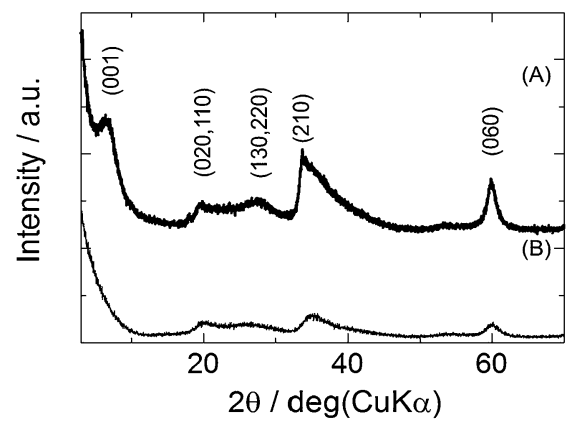

Fig. 1. X-ray diffraction patterns of synthesized smectite powders; (A) $\mathrm{Zn}$-smectite and (B) Mg-smectite. 

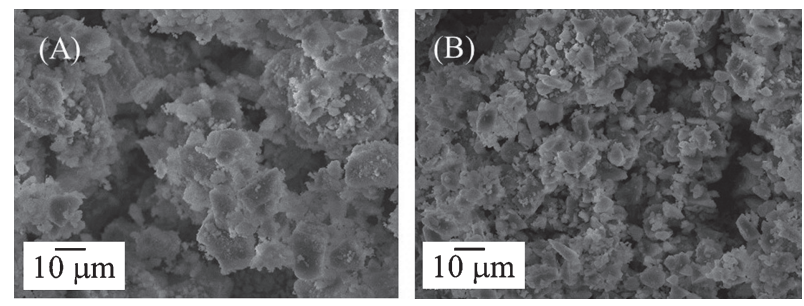

Fig. 2. SEM micrographs of synthesized smectite powders; (A) Znsmectite and (B) Mg-smectite.

Table 1. Molar ratio of synthesized Mg- and $\mathrm{Zn}$-smectite

\begin{tabular}{cccccc}
\hline \multirow{2}{*}{ Sample } & \multicolumn{5}{c}{ Molar ratio (mol \%) } \\
\cline { 2 - 6 } & $\mathrm{Zn}$ & $\mathrm{Mg}$ & $\mathrm{Si}$ & $\mathrm{O}$ & $\mathrm{Na}$ \\
\hline Mg-smectite & - & 15.94 & 24.68 & 58.79 & 0.59 \\
Zn-smectite & 13.79 & - & 16.52 & 61.48 & 8.25 \\
\hline
\end{tabular}

the peak of (001) disappeared in Mg-smectite was thought to be due to the occurrence of disorder in the synthesis process. The crystalline smectite powders were observed by scanning electron microscopy (SEM; JCM-5100, JEOL, Tokyo, Japan). The SEM micrographs of the synthesized powder are shown in Fig. 2. The composition of these samples was measured with a field emission-scanning electron microscope (FE-SEM; JSM-6330F, JEOL Ltd., Tokyo, Japan). The molar ratio of $\mathrm{Mg}$ - and $\mathrm{Zn}$ smectite is described in Table $\mathbf{1 .}$

Although the macroscopic shape of $\mathrm{Zn}$-smectite was different from that of $\mathrm{Mg}$-smectite, aggregated particles in the range from 10 to $50 \mu \mathrm{m}$ were observed in both powders.

To examine the bacterial adsorption effect of the synthesized powder, a bacterial adsorption test was performed. Staphylococcus aureus (NBRC 12732) (hereafter, S.aureus) was used as the test bacteria. The bacteria were cultured in Lysogeny Broth medium (LB medium; Nacalai tesque, INC, Tokyo, Japan) at $37^{\circ} \mathrm{C}$ for $36 \mathrm{~h}$ on a reciprocal shaker. The bacterial culture was rinsed with sterile Dulbecco's phosphate-buffered saline (-) [hereafter, D-PBS $(-)$ ] to make a bacterial suspension. The bacterial suspension was diluted to a final concentration of $10^{8}-10^{9}$ $\mathrm{CFU} / \mathrm{ml}$ (CFU: Colony forming units). The bacterial adsorption test was performed as follows: Dry heat-sterilized smectite powder and D-PBS $(-)$ were mixed to prepare a powder slurry having a powder concentration of 0 to $1 \mathrm{~g} / 1$. The bacterial suspension and the smectite powder slurry were mixed, and the powder concentration was adjusted to range from 0 to $0.5 \mathrm{~g} / 1$. It was then agitated at $37^{\circ} \mathrm{C}$ for $36 \mathrm{~h}$. After agitation, $50 \mu \mathrm{l}$ of supernatant liquid was collected and spread on the pearl-core plate count agar. The bacteria were cultured at $37^{\circ} \mathrm{C}$ for $24 \mathrm{~h}$. The colonies that formed on agar were counted as the residual amount of S.aureus (i.e. unadsorbed amount of bacteria on synthesized smectite powder). Figure 3 shows the change in the residual amount of S.aureus in D-PBS $(-)$ with the powder concentration of smectite. A slight decreased residual amount of S.aureus was observed in the Mg-smectite slurry. In contrast, bacterial suspensions including Zn-smectite powder showed sharply decreased residual amounts of S.aureus with increases in the powder concentration as shown in Fig. 3. These results indicate that smectite powder does have bacterial adsorption characteristics. In addition, it was found that $\mathrm{Zn}$-smectite has a higher bacteria adsorption effect than Mg-smectite.

Discrimination of live and dead bacteria was performed by using a fluorescent staining method. Carboxyfluorescein diacetate

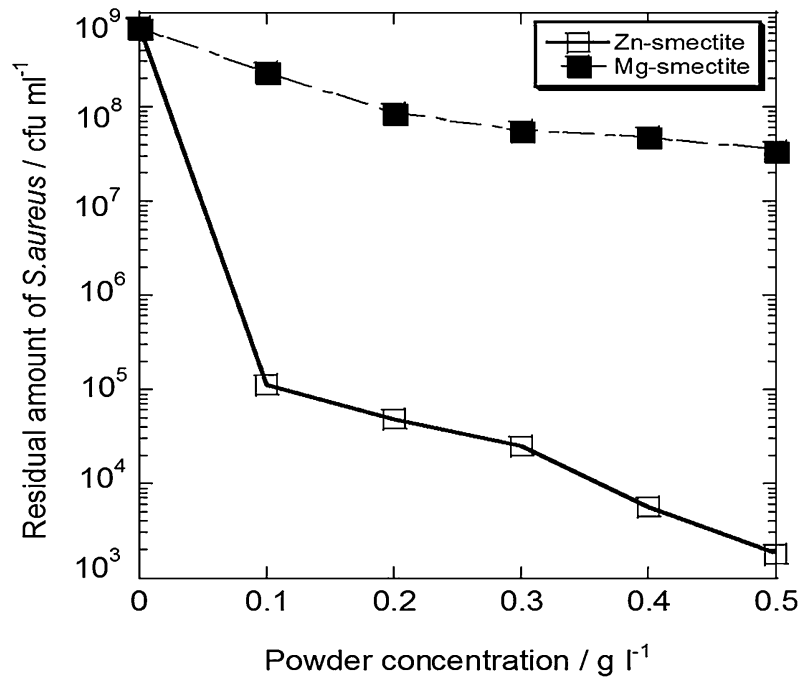

Fig. 3. Changes in the residual amount of S.aureus in D-PBS(-) with the powder concentration of smectite.

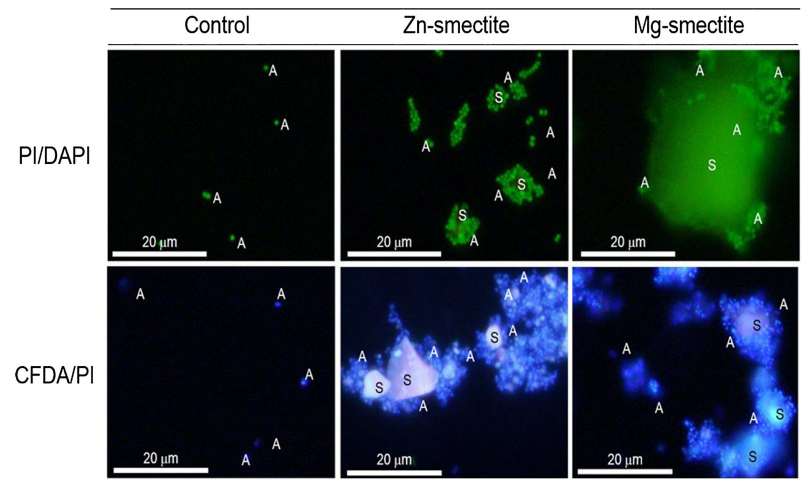

Fig. 4. Fluorescent staining images of S.aureus adsorbed on the smectite powder; A and S refer to S.aureus and smectite powder, respectively.

(hereafter, CFDA) and propidium Iodide (hereafter, PI) stain live and dead bacteria, respectively. However, 4',6-Diamidino-2phenylindole dihydrochloride (hereafter, DAPI) stains both live and dead bacteria. Further study was conducted on the survival status and cell membrane damage of bacteria adsorbed to smectite powder using double staining CFDA/PI and PI/DAPI. Fluorescent staining images of S.aureus adsorbed on the smectite powder are shown in Fig. 4. In the CFDA/PI staining images, many bacteria were observed with green fluorescence adsorbed on the smectite powder. Additionally, in the PI/DAPI staining images, the bacteria adsorbed to the smectite powder showed blue fluorescence. This suggested that the bacteria adsorbed to the smectite powder were live bacteria and had no damage to the cell membrane.

In summary, it was confirmed that synthesized Zn- and Mgsmectite have bacterial adsorption effects for S.aureus with $\mathrm{Zn}$ smectite exhibits a more pronounced effect. Our hypothesis is that the bacterial adsorption of zinc-ion and magnesium-ion intercalated synthesized smectite can reduce bacterial infection and promote wound healing.

\section{References}

1) M. Borisover and J. A. Davis, "Natural and Engineered Clay Barriers", Edition: 1st, Chapter: 2, Elsevier, Amsterdam (2017) 
pp. 34-55.

2) M. Akçay, J. Colloid Interf. Sci., 296, 16-21 (2006).

3) L. B. Williams and S. E. Haydel, Int. Geol. Rev., 52, 745-770 (2010).

4) H. Nam, T. Ebina, R. Ishii, H. Yokota and F. Mizukami, Appl. Clay Sci., 46, 209-215 (2009).

5) M. E. Parolo, L. G. Fernández, I. Zajonkovsky, M. P. Sánchez and M. Bastion, "Science against microbial pathogens: communicating current research and technological advances", Microbiology series 3, Formatex, (2011) pp. 144-151.

6) S. Lantenois, R. Champallier, J.-M. Beny and F. Muller, Appl. Clay Sci., 38, 165-178 (2008).

7) Y. Sasaki, G. A. Sathi and O. Yamamoto, J. Ceram. Soc. Jpn., 124, 1199-1204 (2017).

8) Y. Sasaki, G. A. Sathi and O. Yamamoto, Mater. Sci. Eng., C,
77, 52-57 (2017).

9) S. R. Kim, J. H. Lee, Y. T. Kim, D. H. Riu, S. J. Jung, Y. J. Lee, S. C. Chung and Y. H. Kim, Biomaterials, 24, 1389-1398 (2003).

10) B. Kim, S. Yang, J. Yoon and J. Lee, Clin. Oral Implan. Res., 28, 49-56 (2017).

11) M. Arnold and A. Barbul, Plast. Reconstr. Surg., 117, 42S-58S (2006).

12) P. L. Phillips, R. D. Wolcott, J. Fletcher and G. S. Schultz, Wounds international, 1, 1-6 (2010).

13) C. S. Pasqua, M. Ohnuma, Y. Matsushita, K. Tamura, H. Yamada, J. Cuadros and J. Ye, Appl. Clay Sci., 48, 55-59 (2010).

14) K. Torii and T. Iwasaki, Chem. Lett., 15, 2021-2024 (1986). 